\title{
The Best of Both Worlds: From Volunteer Subtitling to Professional Subtitling
}

\author{
Ebru ÇAVUȘOĞLU*
}

The prevailing technological feasibility has enabled the rise of the digital era and has contributed to the seemingly changing nature of translation. One of the implications of this shift has been articulated in the area of Audiovisual Translation with the emergence of online communities of volunteer subtitle translators. This paper explores the emerging phenomenon of 'volunteer subtitling' and tries to shed light on its role in the transition to 'professional subtitling.' Volunteer subtitling platforms are broad communities of practice that consist of thousands of actively involved members. Despite the increasing interest in investigating various issues regarding online volunteer translation, not much is known about the process of transition from the volunteering world into the professional one. Using the most popular Turkish subtitling platforms (Turkcealtyazi.org and Planetdp.org) as a case study, this paper will present the very first insights into this transition through an analysis of a survey with translators who started their subtitling practice as volunteers and then moved into the professional world. Based on the analysis of the respondents' experiences, it will be argued that the volunteer praxis and the active support of the online community strategically contribute to the improvement of a wide array of translation skills and open up the door for the move into the professional world. In doing so, this paper will also shed a light on both volunteer and professional environments from various perspectives like working conditions, the translation process, types of the work, and translator motivation.

Keywords: volunteer subtitling; professional subtitling; online communities; collaborative online translation; translation process

\section{Introduction}

The growth and the fast dissemination of technology and the Internet have provided a wide range of research subjects in the field of Audiovisual Translation (AVT). As one of those areas, the phenomenon of volunteer subtitling has spread exponentially with the advent of technology and has attracted dedicated research over the last two decades under various terms, such as fansubbing (Díaz Cintas and Muñoz Sánchez 2006), user-generated translation (O’Hagan 2009), social subtitling (Talaván and Ávila-Cabrera 2016), non-professional

\footnotetext{
* Academic at Samsun University; PhDc at Universitat Autònoma de Barcelona.

E-mail: ebru.cavusoglu@e-campus.uab.cat; ORCID ID: https://orcid.org/0000-0003-1666-6002.

(Received 1 September 2020; accepted 3 December 2020)
} 
subtitling (Orrego-Carmona and Lee 2017), amateur subtitling (Bogucki 2009), crowdsourcing (Fernández Costales 2013), and online collaborative translation (Yu 2019).

Accordingly, by taking advantage of Internet technologies, foreign audiovisual media products have become available to a larger audience. Based on this fact, the demand for both professional and non-professional subtitle translation has increased. With the potential offered by the ease of interaction on the Internet, many fansubbing communities have emerged around the world (Orrego-Carmona and Lee 2017). Today, there are thousands of fansubbers all around the globe, translating and reaching various audiences in various regions and languages. The number of volunteer subtitle translator groups has also grown in Turkey. Most Turkish viewers do not understand English-spoken TV shows and films because of not having adequate knowledge of English. Therefore, subtitles are needed to access these media products, and there is a group of people who generally provide subtitles for these contents online on a voluntary basis, unlike professional subtitles of TV shows that cost money (Bayar 2012).

The paper aims to explore the volunteer subtitling activity by focusing on its role in the transition from the volunteer subtitling world into the professional one and, based on this perspective, present an overview of this transition process. With this aim in mind, the purpose of analyzing the case study is to draw attention to this process of transition between two different worlds and unfold the volunteer aspect of the experience. Volunteer subtitling enhances the translation skills of the volunteer translators and encourages them to move forward into a professional world by providing an environment in which they can collaboratively learn and improve. Minako O'Hagan $(2008,177)$ pinpoints the significance of fansubbing activity for the field of translation studies and translator training by stating that "this is indeed an area worthy of further attention by scholars of Translation Studies, particularly those working in the field of translation pedagogy." David Orrego-Carmona $(2013,142)$ reports that the translation students who took part in his study found "the non-professional translation activities as engaging projects that could provide them with skills they will need in the future if they decide to become translators." It seems possible to view the voluntary undertaking in translation from the perspective of translation training in its role to prepare the volunteer subtitlers for the professional world.

In view of these developments, the present paper firstly provides an overview of the origins and the development of volunteer subtitling followed by a review of two different online volunteer subtitling websites (Turkcealtyazi.org and Planetdp.org) in Turkey. Then, it draws 
focus on the professional subtitling world before moving on to the results and the discussion drawn from the electronic survey conducted with six Turkish translators who currently work as professional translators in different platforms from TV channels to translation agencies and once have been volunteer translators in online communities in Turkey. The survey addresses the following interlocking questions to obtain the data that may help to gain insight into both subtitling worlds in Turkey: (1) How was the process of transition from volunteer subtitling into professional subtitling? (2) In what ways the volunteer experience helped or did not help you in your journey towards the professional world? (3) What are the differences between these two areas (e.g., in terms of working conditions, the translation process, the products to be translated, workflow, and so on)? Lastly, conclusions and some ideas for further research are presented.

\section{Origins of Volunteer Subtitling}

The development of the Internet as an interactive medium is giving rise to a series of creative non-professional translation practices (Pym 2012). With the appearance of Web 2.0 the second generation of the World Wide Web-Internet users became capable of reaching and producing things on a self-driven motivation, and the users could easily create online communities and share information with each other. With the easiness of the direct interaction, this platform encouraged the translators to carry on online translation projects ( $\mathrm{Su} 2017,119)$. It is a fact that these online communities disseminate at a breakneck pace. The collaborative translation practice has evolved from what was known as fansubbing in the 1980s when fans of Japanese anime in the US engaged directly with the content by translating and sharing the animation (Orrego-Carmona and Lee 2017). "Most conspicuous initially with Japanese anime fansubs, fan-based translation has been developing since then" (O'Hagan 2009). Emerging with the name of the 'fansubbing' activity, volunteer subtitling has expanded into several forms of audiovisual content. The non-profit nature of this concept led to the growth of volunteer subtitling into a broader scale not only in the world of anime but also in various modern media genres and texts. Tessa Dwyer $(2019,438-440)$ acknowledges that the term 'fansubbing' is historically tied to Japanese 'anime,' but in today's world "with the explosion in fansubbing facilitated via digitization and online networking, fan AVT entered its present post-anime phase characterized not by any dearth of anime content but rather by huge expansion into diverse 
genres, languages, countries, and contexts." Today, the concept of fansubbing encompasses all types of audiovisual content (He 2014, 310).

Łukasz Bogucki $(2009,49)$ refers to this newly emerged type of translation as "amateur subtitling" by underscoring that "the ubiquity of the Internet, however, has given rise to a new kind of AVT.” Jorge Díaz Cintas and Pablo Muñoz Sánchez (2006) have foreseen the potential that the fansubbing has, and according to them, subtitling conventions are not set in stone, and only time will tell whether these fansub conventions are just a mere fleeting fashion or whether they will spread to other media and become the seed of a new type of subtitling for the digital era. As Alberto Fernández Costales (2011) postulates, "fan translation, or the adaptation of multimedia products by amateur translators, has been clearly propelled by new technologies and is a phenomenon that can hardly be avoided." Broadly speaking, the aforementioned studies refer to that the activity of fansubbing has become a global phenomenon illustrating the prompt development of economic and cultural globalization encompassing the existence of affordable and accessible computer technology (Zhang 2013).

According to María Rosario Ferrer Simó (2005), fan translation has become a major phenomenon on social media within a big range of virtual communities on the Internet like in websites, chat rooms, forums, and so on. In this same vein, it can be inferred that volunteer subtitling communities, emerging as a fan-based activity, cover an astounding spectrum of applications of the concept of online collaborative communities by encouraging volunteer translators to take part in online translation in an open online community. Wiki translation is one of the instances of non-professional online volunteer translation, and as Miguel Ángel Jiménez-Crespo $(2017,32)$ defines, "wiki translation is an open model" where the volunteers impart by adding their own translation to be edited later on by other members. "The final text" is shaped by the incorporation of the contributions. Amara, Wikipedia, and Transifex are some of the samples for this wiki translations model.

Enabled by technology in the modern age, another website TED.com delineates the potency of volunteer subtitling with the aim of making all talks accessible for the listeners and viewers around the globe. By adding subcategories such as TEDxTalks, TedED lessons, and also as an application for smartphones and tablets, there is a considerable amount of growth in the open translation project of subtitles on the TED website. As it is mentioned on the website's "Translate" section: "TED Translators are volunteers who subtitle TED Talks, and enable the 
inspiring ideas in them to crisscross languages and borders." Today, TED online volunteer translators community has over 38,475 translators in 115 languages. ${ }^{1}$

These statements show that volunteer subtitle communities have a solid ground that functions by creating a collaborative environment with authentic participation. Based on the collected data range from TED.com, Maeve Olohan (2014) concludes four basic factors that maintain continuous volunteer workflow such as sharing ideas and creating global knowledge, creating social change, the sense of satisfaction, feeling of belonging to a certain group. "It seems that the personal desire to contribute to the spread of information or to allow other people to read and access materials in their own language are both underlying features in all these phenomena” (Fernández Costales 2013, 92).

\subsection{Volunteer Subtitling Websites in Turkey}

To date, translation practices on the Internet have adopted a context in which the evergrowing fan communities, along with the vast technological advances, have enabled a new type of subtitling that entails both individual and collaborative work within online communities (Talaván and Ávila-Cabrera 2016, 127). Reflecting on this statement, such evolution can also be observed in Turkey in the great demand for subtitles to meet the need of the market in the TV and movie business.

In this part, two Turkish volunteer translator websites will be dealt with regarding some of their features like the section of the forum, other sections, users' profiles, and the workflow.

2.1.1 TurkçeAltyazi.org. 'Türkçe altyazı' means 'Turkish subtitle,' and this currently active volunteer subtitle translators' community was founded in the year 2007 and has 226,589 registered members, 652,125 subtitle files, and 370,464 comments. $^{2}$ It is user-friendly, and it also has a forum section containing various topics assisting translators' work and creating a friendly, sincere, collaborative platform for all members. Other than providing Turkish subtitles for films and TV series, the website also has sections such as news about films, series, and also critics, special files, and so on for the viewers to be able to enjoy reading and getting information about the media from all over the world.

\footnotetext{
1 “Translate," TED.com, accessed December 13, 2020, https://www.ted.com/participate/translate.

2 The data was collected on October 29, 2020.
} 
As a non-profit online subtitling website, the main aim of TurkceAltyazi.org is to make subtitle translations available for the viewers by creating a platform for the users to be involved in the translation activity as well. Anyone can sign up as a user/member of the website and, upon a desire, anyone can translate while getting the assistance they need from more experienced users and from the section where they can find all the necessary information about the translation process, the workflow, and the stages of becoming a translator on the website. The way the community is structured does not carry any distinct separation or a very strict hierarchy in the community.

2.1.2 PlanetDP.org. PlanetDP.org is another online volunteer subtitling website, and it is a continuation of the non-professional Turkish-speaking subtitling group called DivXPlanet.com. ${ }^{3}$ After being banned under the name of DivXPlanet, the website again appeared by another name as Altyazi.org until February, 2017, and currently, it continues with the name of PlanetDP.org. This highly active community was founded in 2017 by the same admin team from DivXPlanet.com, and it still includes the vast content inherited from DivXPlanet.com since 2014.

As mentioned on PlanetDB.org, ${ }^{4}$ the aim of the website is to make subtitles available to film lovers and maintain satisfaction among the members and the viewers by taking into consideration their feedback and by growing with their participation and support. Through renewing its subtitle database and the portal, the website prioritizes its members and viewers in order to present them with updated content. The group of members in this online volunteer subtitle translator community work in a structured and collaborative way as in the previously reviewed website TurkceAltyazi.org. On the forum platform where constant communication exists, various video tutorials and guidelines are provided in order to present instructive information on how to learn about subtitling best practices from both technical and linguistic aspects.

\footnotetext{
${ }^{3}$ First founded in 2004 and terminated in November, 2014.

4 "Hakkımızda" (About us), PlanetDP.org, accessed December 16, 2020, https://planetdp.org.
} 
Figure 1. Statistics ${ }^{5}$ on PlanetDP.org

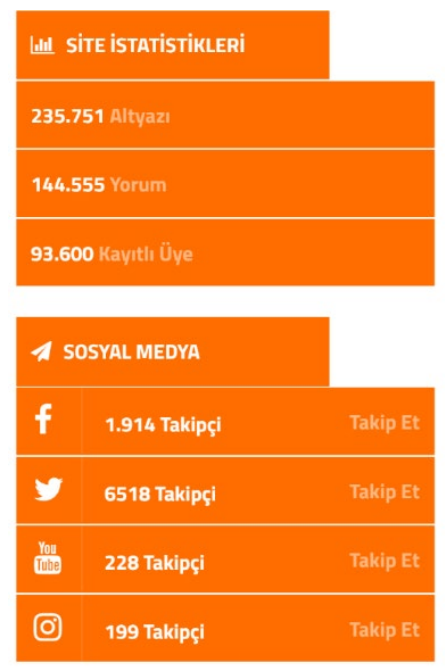

With its user-friendly interface, PlanetDP.org also offers an opportunity for all viewers to browse its rich database of content. There is a distinctive tenet of this website: the bilingual option of the forum section on the website (Turkish and English). Also, as can be seen in figure 1, the website integrates the online social media platforms into its content. On the YouTube channel, there is user-generated content where the viewers can find trailers with Turkish subtitles embedded, the lists of films, the features of PlanetDP.org, how to use those features, and so on. ${ }^{6}$ Given the overall analysis of the website and its structure, it can be denoted that the dedication from the volunteer translators is observed on various levels.

\section{Professional Subtitling in Turkey}

Translation has only been regarded as an independent profession since the midtwentieth century, triggered by the digital revolution in the 1990s and the immense proliferation in translation demand (Garcia 2009, 200). Similarly, it was not until the 1990s that AVT was recognized as a professional practice with the increase and the allocation of audiovisual products (Díaz Cintas 2008, 1). These aspects are particularly noteworthy in view of the late acceptance of the translation as a profession. In Turkey, the state of professional translation is no different. Translatorship still has not realized its "professionalization process" in Turkey

\footnotetext{
${ }^{5}$ The statistics were accessed on May 17, 2020. The screenshot reads "Site Statistics: 235,751 Subtitles, 144,555 Comments, 93,600 Registered Members" and informs about social media followers. There is also a "Takip Et" (Follow) button for each platform.

${ }^{6}$ YouTube channel of PlanetDP.org, accessedMay 17, 2020, hittps:/www.youtube.com/channel/UCTDolGxwf2qopVzlhQouY3A/playlists.
} 
albeit being "one of the oldest professions" in history (Uysal, Odacioğlu, and Köktürk 2015, 257).

The definition of the term 'professional' in the field of translation is proposed within comparison to the 'non-professional' subtitling by Ahsen Ay (2019, 40): "Education, specialized knowledge, monetary award, association or a combination of these criteria can grant translators a professional title and could also be used to distinguish professional translators from non-professional ones."

In professional subtitling in Turkey, it has been put forward that there are certain rules and regulations asserted by the industry (e.g., employers and The Radio and Television Supreme Council), and the subtitle translators are bound to follow them (Erguvan 2016, 147). However, in a free of charge volunteer-based activity, professional codes are not considered as a compelling factor (Y1ld1z 2017, 41).

The professional world is delineated within a more formal framework. As also stressed by Fang Wang $(2014,1905)$, "the professional translators always talk about what translation principles to follow, or what kind of methods to use. But the fansub members seldom think about that, they just translate any way they want as long as it is "suitable." To further the characteristics of the professional subtitling in Turkey, A. Sirin Okyayuz (2016) touches upon the notion of censorship and compares the social subtitling (referring to online volunteer subtitling) for Internet sites with the professional institutional subtitling for TV channels and asserts that the challenges of subtitling for TV channels in Turkey would be the censor to the text alongside the regular subtitling constraints such as "the rendering of speech with text, the limitation, and the bonus of having the visual track" (212).

Professional subtitlers pursue the norms of 'best practice' of their industry and provide high-quality subtitles; on the contrary, the fansubbers (volunteers), generally being self-taught, are not deemed by their viewers by professional standards, and the quality of the fan products may vary (Wilcock 2013). Apart from the quality of the subtitled product, there is a considerable amount of concerns mulled over in research regarding the comparison of professional and volunteer translation work. O'Hagan $(2009,26)$ raises some questions concerning the volunteer "crowdsourced" translation practice by expressing matters such as "ethical issues, quality, genre knowledge and general motivation." In this same vein, as Mehmet Y1ldiz $(2017,41)$ postulates, legality and ethics are gauged among the issues linked to volunteer translation. 
In light of the ample research done, it is safe to say that volunteer translation can be placed in the periphery of the translation profession. The final position of the volunteer translation is not predictable, both professional and non-professional practice "can coexist without being in competition" (Flanagan 2016, 164).

\section{Results and Discussion}

Against the backdrop of this paper's objective, the triggering idea is to explore the function of volunteer experience on the way to the professional world. Six translators willing to participate in the electronic survey conducted through Google Forms ${ }^{7}$ represent TV channels and also translation agencies that provide subtitles for DVDs, airlines in-flight entertainment, and also online platforms such as Netflix.

This part of the paper is intended to provide an overview for both professional and volunteer subtitling platforms based on the responses obtained from the translators who were once volunteers and currently work as professional translators.

\subsection{The Transition Process from Volunteer Subtitling into Professional Subtitling}

\section{Respondent 1:}

After gaining confidence through the experience as a volunteer subtitler for a long time (since 2009), I thought to myself, "Why don't I try this in a professional context?" and I applied to agencies. The process started this way. I've been working professionally since 2012 and still, I'm translating voluntarily as well.

\section{Respondent 2:}

I started to translate voluntarily in 2003. One agency that is a subtitle and dubbing provider reached me via the online platform (divxplanet.com) where I was doing subtitle translation. In this way, I started translating professionally.

\section{Respondent 3:}

After practicing volunteer subtitling approximately for 6 years, one agency reached me, and I stepped into the professional world through them.

\section{Respondent 4:}

I started translating professionally through the online volunteer translators website. I applied to an agency and thanks to the mask [refers to the title given to the translators whose translations are considered as in the frame of good subtitling after a certain

\footnotetext{
${ }^{7}$ The survey questions were prepared in English, and the translators mentioned that they were more comfortable answering them in Turkish. Therefore, the responses below were translated into English by the author.
} 
number of translations produced regularly and meaning that they are reliable translators] that I gained on the website, they accepted my application.

\section{Respondent 5:}

With the advantage of fame coming within the online platform after translating voluntarily for a long time, I received job offers. In the beginning, I also kept translating professionally along with the volunteer translation, and I wasn't thinking that it would be my profession. However, after a while, many doors were opened for me, and since I love translation, I'm currently doing it only professionally.

\section{Respondent 6:}

I received a job offer from a company that was following my volunteer translations online.

On the basis of the responses to the first question that explores the beginning of the journey into the professional world, it is necessary to point out that the experience of volunteer translation has played a significant role in providing the translators with fame or courage to move forward in their career. A number of well-known companies have realized the potency of volunteer production (Jiménez-Crespo 2009, 68), and in line with this statement, 4 out of 6 translators emphasize the fact that the volunteer platform supported them in paving the way for being recognized by the industry.

Two translators express the role of the volunteer experience regarding encouragement that drives them to initiate their own career development towards the professional world. Volunteer experience enables the translators to embody a more creative approach in order to appeal to their audience in an 'interesting' and 'intelligible' way; therefore, they tend to 'innovate,' and this fact amplifies their faculty of "initiative, authority and agency" (PérezGonzález and Susam-Saraeva 2012, 158) in delivering their product.

Gauging the extent to which volunteer experience has contributed to the professionalization of the volunteer translators, it is possible to conclude that it has a supporting role pertaining to the transition from the volunteer translation into the professional translation.

\subsection{The Impact of the Volunteer Experience in the Journey towards the Professional World}

\section{Respondent 1:}

The volunteer experience supports me in terms of being known. When I applied to some agencies, I received an answer saying that they knew me and they had been following my translations fondly on the website. Therefore, my recruitment process was really fast. 


\section{Respondent 2:}

Volunteer translation has helped me to gain confidence in translation and also enhanced my language skills both in English and Turkish. Actually, for me, it functioned the other way around. Professional translation contributed to my experience in the translation field in terms of the quality control process. During volunteer translation, I used to have some points that I missed, such as punctuation, spelling, and translation itself. With the help of feedback from the control mechanism, my translations have become more proper.

\section{Respondent 3:}

My transition into the professional world was thanks to my experience as a volunteer translator. The name and the popularity I gained in that online platform helped me to receive job offers.

\section{Respondent 4:}

Even though the online platform is set on a volunteer basis with no profit, they do have their own regulations and guidelines in subtitling to provide standardization. With the assistance of this fact, I became familiar with the subtitle formats and various programs. I can say that the volunteer experience served as an internship for me in order to produce good subtitles. However, as a disadvantage, I can say that compared to the professional world, they act more freely, and there is no patronage or hierarchy. You are on your turf and you can use any slang or jargon. On the other hand, in the professional world as a translator, you have to translate by abiding by the rules and regulations. In short, the freedom you are used to while translating voluntarily is taken away from you once you start the professional translation.

\section{Respondent 5:}

I had no experience when I first started volunteer translation. Of course, I can't say that I'm done and complete as a translator right now; however, the volunteer work that I've done for 15 years has contributed to me a great deal. It helped me a lot in terms of expanding my vocabulary in English, my acquisition with the English sentence structures, and easier analysis of the spoken texts, and as the phrase goes, thanks to my volunteer experience, I'm able to render my own style of the language in my translations. Above all, all those years I've improved my language and translational skills. If I had started from zero in the professional world, I don't believe that I would have stayed and made my way in the professional world.

\section{Respondent 6:}

You improve yourself through translating. I improved myself in translation mostly during my experience in the online volunteer translation. I've always had the benefit of my technical knowledge in subtitling.

It goes without saying that the responses on the ways how the volunteer experience impacted the transition from the volunteer world into the professional pinpoint the notion of improvement in terms of translational and language skills. It also appears that the volunteer 
subtitling has benefited the translators through serving as a recruitment phase before stepping into the professional world.

Two respondents have mentioned that the volunteer subtitling has acted as an intermediary in developing their English and Turkish proficiency. It is worth reiterating that amateur production of the subtitles for audiovisual products contributes to the process of language learning by catering to the linguistic and the social engagement of the learners (Lakarnchua 2017). Also, as noted by Wang $(2014,1907)$, "it connects closely with social development, enlarges the translation scope, and promotes the development of translation. Besides, it also improves reading skills, boosts foreign language skills, and facilitates easy and cheap international program exchange."

In addition to its being an educational tool in the improvement of language skills, the rest of the respondents referred to the volunteer subtitling as a feasible experience similar to the recruitment process that supports them with the technical and translational skills entailed in subtitle translation. Volunteer translators amass the knowledge that encompasses both the linguistic and technical requirements of translation in a volunteer platform.

\subsection{The Differences between Two Areas (Volunteer Subtitling vs. Professional Subtitling)}

\section{Respondent 1:}

While I was translating as a volunteer translator, I was only doing subtitle translation and with starting to work professionally, I became acquainted with dubbing and I discovered how different dubbing expertise was. As it comes to working conditions, surely there is no unlimited time like in the volunteer platform, there is a tight deadline in the professional world. There is also no luxury like choosing what to translate or to translate the materials that interest you; on the contrary, you have to translate whatever comes your way according to your availability.

\section{Respondent 2:}

The biggest difference was earning money. Other than that, depending on the platform there are censorship issues applied in the translation.

\section{Respondent 3:}

The enjoyment with the products you translate and the pleasure gained from the final product are much more intense in the volunteer translation. The reason for this is the freedom to choose whatever you want to translate. I can say this is the small prize of the volunteer translation. When it comes to professional translation, you have to do whatever is assigned to you. As the name implies, it is professional. The working conditions vary on both platforms. Our job is always urgent in both cases, volunteer 
work pushes you with the fan viewers waiting on your translation and the deadlines limit you in the professional world. Frankly, translating in an ideal way-which is to translate by taking your time and examining thoroughly - is a bit of a luxurious notion in this sector.

\section{Respondent 4:}

With regard to working conditions, the time limitation is always there. I was trying to let the viewers have the subtitles that I produced as soon as possible during volunteer translation, and I was enjoying this rush a lot. I liked the fact that many people were thanking me for this. My working hours in volunteer translation were mostly shaped around the series that was broadcasted at the same time and as a matter of fact, I was even translating in a shorter time compared with the professional translation. Some series were broadcasted at night and I remember staying up many nights or waking up very early in the morning in order to translate the new episode. Currently, since I work as a freelance translator, I plan my hours and I try to do translation at more reasonable hours. Regarding the products, the translation was always from foreign sources into Turkish and when I started working professionally, I also started to translate from Turkish to English. In volunteer translation, I rarely had the source problem and I always translated from a written source text. However, professionally I had to do subtitle translation without the source, time code, and producing the translation from zero. In the volunteer world, I only had this kind of problem in the translation for the deaf and hard of hearing.

\section{Respondent 5:}

I can say that the volunteer subtitling platform, except for some rules, is much simpler than the professional world of translation. Professionally, you have to obey many rules. In a volunteer translation, if the quality of your translation is good enough, there may be many points that are tolerated, but in a professional translation, there is no toleration. The control mechanism in the volunteer world isn't as strict as in the professional world. In a volunteer translation, you decide your deadline; however, the only backdrop here is that the attrition of the viewers waiting for your subtitles impatiently wears the translator out morally. However, in the professional sector, you always have a deadline, and you have to complete and submit the translation by that specified time. In other words, in the first, it is all up to you, but in the latter, the employer calls the shots. Also, in the professional world, you can't choose what to translate. Of course, you still have the right to accept or to refuse the work, but if you work for a certain company, you usually end up receiving the work. Moreover, in the professional world, you can't even find a bit of the pleasure that you have in the volunteer work, but on the other hand, you can't find the financial profit that you get professionally in the volunteer work. In a professional world, they only care about the understandability of the translation rather than the quality of the work. Because they don't want the translation to take the role of the production and the viewers to be overwhelmed with the subtitles. Since they apply certain character limitations, the translator experiences a lack of pleasure in the work. In the volunteer work, the translator spends time presenting the translation in the best way and just because of this, when the translation is good, it often gets ahead of the production. 


\section{Respondent 6:}

In a much shorter time, you have to do a more controlled job. There are more technical rules, and if you are translating for a local TV channel, then there is a censorship issue. You can't be selective like in the volunteer translation. If you refuse every job offered to you, then you starve, and for this reason, usually, you have to translate the films or series that you don't actually like.

As can be noted from the responses to the last question that seeks to discover how the two worlds differ, the data can be classified under the concepts of 'working conditions,' 'the translation process,' 'types of work,' 'motivation,' and 'satisfaction.'

'Working conditions' are more structured in the frame of rules and regulations in the professional world. "It is true that, as an amateur phenomenon, fansubbing does not have to comply with the norms that govern professional subtitling" (Bruti and Zanotti 2012, under "Abstract"). In terms of 'the translation process' in both worlds, there is a notion of a deadline imposed by different sources. In volunteer practice, the translators are driven intrinsically to meet the demand of the audience. According to Elena Di Giovanni $(2018,20)$, audiences play an active role in the "consumption/reception" and also in some phases of the production process. In the professional world, there is a formal deadline already set by the employer. Two of the volunteer translators denote that there are mutual pleasure and enjoyment between the fans and the volunteer translator. Y1ldiz $(2017,53)$ concludes that 'fansubbing' (volunteer translation) is not just a spare time activity, and it surpasses the professional skills. Also, it is an activity formed by "fansubbers and the viewers" in an environment where a unique bond exists that is not quite possible to be built in a professional world. Additionally, 4 translators out of 6 mention that professionally, the translators are entailed to translate the material that is assigned to them, contrary to the volunteer world where they are allowed to select the material to be translated.

\section{Conclusions}

The Internet has been recognized as the main supplier for audiovisual content with a wide variety of content solely in their original language around the world, leading "amateur subtitling" or "fansubbing" to spread and become "popular" for "accessing previously unavailable or incomprehensible content" (Wilcock 2013,1). On the other hand, with the rise of the phenomenon of volunteer subtitling, concerns have arisen regarding the legality of the 
practice (Condry 2010) and the linguistic quality of the subtitles (Nornes 1999; Díaz Cintas and Muñoz Sánchez 2006).

The present paper has attempted to focus on this common practice of volunteer subtitling based on a corpus of a survey with Turkish volunteer translators who now work as professional translators, with the objective of demystifying this transition process from the volunteer world into the professional world.

The findings of the study suggest that the volunteer subtitling experience contributes to the career of translators in a professional world. In addition to exploring the complementary feature of volunteer experience as an advantage in the transition process into the professional world, reflecting on the responses gathered from the translators has disclosed that volunteer subtitling and professional subtitling are applied in different conditions. Mehmet Şahin (2018, 83) postulates that in professional translation in Turkey, the amount of the control is intense, and it decreases the rendering of the original in the case of subtitled audiovisual products on TV while fansubbing practice is becoming disseminated with this control broken down.

In the same vein, the responses coming from the translators reveal that the distinction between the two worlds and the control mechanism turned out to be mainly indicated together with the enjoyment and the satisfaction experienced in the translation process. An online platform has given the volunteers the flexibility to pursue their interests along with providing them with the opportunity to choose the material to be translated. And in terms of the pedagogical aspect of the research, what is reflected in the responses is the contribution of the volunteer work from many perspectives as it comes to the development of the translational skills. The results as discussed above reveal that volunteer translation supported them in their journey towards the professional world by acquainting them with many opportunities in their expertise in the area of translation through providing a platform in which they can make their names known and also by gaining the necessary skills to subtitle with the work they have done on a volunteer basis.

Ultimately, this study has led to conclude that by employing the skills through producing on a volunteer basis on the Internet, the translators improve their language and translation skills and continue to produce work in an online platform for their audiences. In time, they gain the necessary confidence and the skill to reach the professional world or to be discovered by the industry. 
There is no doubt that more research and empirical data are needed for the comparison of the volunteer and the professional world. Especially, in Turkey AVT from the perspective of volunteer subtitling remains under-researched. This article paves the way for further and more in-depth research including viewers, employers, and more translators from both volunteer and professional worlds, since the potency of volunteer praxis is also getting noticed by the professionals, and as Laurinda Cecilia van Tonder (2015, under “Abstract") pinpoints,

When not judged from the stoic perspective of industry 'best practice', an examination of fansubbing holds the potential to provide professional subtitlers with an insight into how these type of creative subtitling practices can offer audiences a richer viewing experience and involve them as active participants in the meaning-making process.

In conclusion, benefitting from the advantages offered by digital technology, volunteer subtitling organizations are growing and "getting better at what they do and it is possible to say that there are non-professional translations that are as good as their professional counterparts and from a Translation Studies perspective, the possibilities offered by this new phenomenon should be acknowledged" (Orrego-Carmona 2016, 178).

Volunteer subtitling communities appear to stay, and "it may not be foreseen to what extent it will impact the professional market but the best way is attempting to comprehend this new way of translating and learn from it" (Bold 2011, 16). Given an account of the experiences by translators, albeit the limited number of the cases in this study, considerable insight has been provided into the significant role of the volunteer experience in stepping into the professional world. The results are encouraging to state that volunteer practice might very well serve for the good of the professional practice and both worlds can coexist by creating a mutual profit. 


\section{References}

Ay, Ahsen. 2019. "A Comparative Analysis of the Challenges Encountered in Literary and Audiovisual Translation of Science Fiction: A Case Study on Ready Player One by Ernest Cline." Master's thesis, Hacettepe University. http://hdl.handle.net/11655/7675.

Bayar, S. C. 2012. "Online Practice of Fan-Based Subtitles: The Case of the Turkish Translators.” Master's thesis, Erasmus University. http://hdl.handle.net/2105/11257.

Bogucki, Łukasz. 2009. "Amateur Subtitling on the Internet." In Audiovisual Translation: Language Transfer on Screen, edited by Jorge Díaz Cintas and Gunilla Anderman, 4957. London: Palgrave Macmillan. doi:10.1057/9780230234581_4.

Bold, Bianca. 2011. "The Power of Fan Communities: An Overview of Fansubbing in Brazil." Tradução em Revista, no. 11, 1-19. doi:10.17771/PUCRio.TradRev.18881.

Bruti, Silvia, and Serenella Zanotti. 2012. "A Linguistic Approach to Non-Professional Translation: Focus on Fansubs." Paper presented at the First International Conference on Non-Professional Interpreting and Translation, University of Bologna, Forlì, 17-19 May.

Condry, Ian. 2010. "Dark Energy: What Fansubs Reveal about the Copyright Wars." Mechademia 5:193-208. https://muse.jhu.edu/article/400557.

Díaz Cintas, Jorge. 2008. "Introduction: Audiovisual Translation Comes of Age." In Between Text and Image: Updating Research in Screen Translation, edited by Delia Chiaro, Christine Heiss, and Chiara Bucaria, 1-9. Amsterdam: John Benjamins. doi:10.1075/btl.78.02dia.

Díaz Cintas, Jorge, and Pablo Muñoz Sánchez. 2006. "Fansubs: Audiovisual Translation in an Amateur Environment." The Journal of Specialised Translation, no. 6, 37-52. https://www.jostrans.org/issue06/art_diaz_munoz.pdf.

Di Giovanni, Elena. 2018. "The Reception of Professional and Non Professional Subtitles: Agency, Awareness and Change." Cultus: The Journal of Intercultural Mediation and Communication 11:18-37. https://www.cultusjournal.com/files/Archives/Elena-DiGiovanni.pdf.

Dwyer, Tessa. 2019. "Audiovisual Translation and Fandom.” In The Routledge Handbook of Audiovisual Translation, edited by Luis Pérez-González, 436-452. Abingdon: Routledge.

Erguvan, Mehmet. 2016. "Venutian Scale in the Realm of Subtitling in Turkey: A Comparative Analysis of the Fansubs and the Official Subtitles of Family Guy." Çeviribilim ve Uygulamalarl Dergisi, no. 22, 147-168. http://fs.hacettepe.edu.tr/ceviribilim/dosyalar/sayilar/sayi22.pdf. 
Fernández Costales, Alberto. 2011. "Translation 2.0: Facing the Challenges of the Global Era." Paper presented at Tralogy I: Translation Careers and Technologies and the Convergence Points for the Future, Paris. http://odel.irevues.inist.fr/tralogy/index.php?id=120.

2013. "Crowdsourcing and Collaborative Translation: Mass Phenomena or Silent Threat to Translation Studies?" Hermēneus: Revista de Traducción e Interpretación, no. 15, 85-110. https://recyt.fecyt.es/index.php/HS/article/view/30295/15892.

Ferrer Simó, María Rosario. 2005. "Fansubs y Scanlations: La Influencia del Aficionado en los Criterios Profesionales." [The influence of fansubbers on professional standards.] Puentes, no. 6, 27-44. http://wpd.ugr.es/ greti/revista-puentes/pub6/04-Maria-RosarioFerrer.pdf.

Flanagan, Marian. 2016. "Cause for Concern? Attitudes towards Translation Crowdsourcing in Professional Translators' Blogs.” The Journal of Specialised Translation, no. 25, 149 173. https://www.jostrans.org/issue25/art_flanagan.pdf.

Garcia, Ignacio. 2009. "Beyond Translation Memory: Computers and the Professional Translator." The Journal of Specialised Translation, no. 12, 199-214. https://www.jostrans.org/issue12/art_garcia.pdf.

He, Tianxiang. 2014. "Fansubs and Market Access of Foreign Audiovisual Products in China: The Copyright Predicament and the Use of No Action Policy." Oregon Review of International Law 16 (2): 307-346. https://ssrn.com/abstract=2685800.

Jiménez-Crespo, Miguel Ángel. 2009. "The Evaluation of Pragmatic and Functionalist Aspects in Localization: Towards a Holistic Approach to Quality Assurance." The Journal of Internationalization and Localization 1 (1): 60-93. doi:10.1075/jial.1.03jim.

2017. Crowdsourcing and Online Collaborative Translations: Expanding the Limits of Translation Studies. Amsterdam: John Benjamins.

Lakarnchua, Onuma. 2017. "Examining the Potential of Fansubbing as a Language Learning Activity." Innovation in Language Learning and Teaching 11 (1): 32-44. doi:10.1080/17501229.2015.1016030.

Nornes, Abé Mark. 1999. "For an Abusive Subtitling." Film Quarterly 52 (3): 17-34. doi:10.2307/1213822.

O’Hagan, Minako. 2008. "Fan Translation Networks: An Accidental Translator Training Environment?" In Translator and Interpreter Training: Issues, Methods and Debates, edited by John Kearns, 158-183. London: Continuum.

. 2009. "Evolution of User-generated Translation: Fansubs, Translation Hacking and Crowdsourcing." The Journal of Internationalization and Localization 1 (1): 94-121. doi:10.1075/jial.1.04hag. 
Okyayuz, A. Sirin. 2016. "Translating Humor: A Case of Censorship vs. Social Translation." European Scientific Journal 12 (8): 204-224. doi:10.19044/esj.2016.v12n8p204.

Olohan, Maeve. 2014. "Why Do You Translate? Motivation to Volunteer and TED Translation.” Translation Studies 7 (1): 17-33. doi:10.1080/14781700.2013.781952.

Orrego-Carmona, David. 2013. "Using Non-Professional Subtitling Platforms for Translator Training." Rivista Internazionale di Tecnica della Traduzione, no. 15, 129-144. http://hdl.handle.net/10077/10611.

- 2016. “A Reception Study on Non-Professional Subtitling: Do Audiences Notice Any Difference?" Across Languages and Cultures 17 (2): 163-181. doi:10.1556/084.2016.17.2.2.

Orrego-Carmano, David, and Yvonne Lee, eds. 2017. Non-Professional Subtitling. Newcastle upon Tyne: Cambridge Scholars. Google Book.

Pérez-González, Luis, and Şebnem Susam-Saraeva. 2012. "Non-Professionals Translating and Interpreting. The Translator 18 (2): 149-165. doi:10.1080/13556509.2012.10799506.

Pym, Anthony. 2012. "Website Localizations." Oxford Handbooks Online. doi:10.1093/oxfordhb/9780199239306.013.0028.

Su, Churan. 2017. "Crowdsourcing Translation under Translational Eco-Environment of Web 2.0.” International Journal of English Literature and Social Sciences 2 (5): 119-123. doi:10.24001/ijels.2.5.13.

Şahin, Mehmet. 2018. "Surmounting Censorship in Subtitles in the Context of Turkey." Parallèles 30 (2): 70-86. doi:10.17462/para.2018.02.05.

Talaván, Noa, and José Javier Ávila-Cabrera. 2016. "Collaborative Networks to Provide Media Accessibility: The Potential of Social Subtitling." In "Innovating in the Didactic Second Language Scenario: New Mobile, Open and Social Models," edited by Cristina Calle Martínez, María Dolores Castrillo de Larreta-Azelain, and Antonio Pareja-Lora. Special Issue, Porta Linguarum 1:125-138. doi:10.30827/Digibug.54095.

Tonder, Laurinda Cecilia van. 2015. "Fansubbing and Creative Subtitling - How Amateur Approaches Can Help Improve Professional Products." In Proceedings of the South African Translators' Institute Second Triennial Conference: The Changing Face of Translation and Interpreting. http://www.academia.edu/download/39053906/Van_Tonder_LC__Presentation_Narrative.pdf.

Uysal, Nazan Müge, Mehmet Cem Odacıŏlu, and Şaban Köktürk. 2015. "Meslekleşme Açısından Türkiye'de Çevirmenliğin Mevcut Durumu, Sorunlar ve Çözüm Önerileri." [Current position of translatorship in Turkey in terms of professionalization, problems, and suggestions.] Journal of International Social Research 8 (36): 257-266. doi:10.17719/jisr.2015369505. 
Wang, Fang. 2014. "Similarities and Differences between Fansub Translation and Traditional Paper-Based Translation." Theory and Practice in Language Studies 4 (9): 1904-1911. doi:10.4304/tpls.4.9.1904-1911.

Wilcock, Simone. 2013. "A Comparative Analysis of Fansubbing and Professional DVD Subtitling." Master's thesis, University of Johannesburg. http://hdl.handle.net/10210/8638.

Yıldız, Mehmet. 2017. "Pirates (!) Strike Back: Turkish Fansubbers Standing up for Fansubbing." COMU International Journal of Social Sciences 2 (3): 39-56. https://dergipark.org.tr/tr/download/article-file/407800.

$\mathrm{Yu}$, Chuan. 2019. "Negotiating Identity Roles during the Process of Online Collaborative Translation: An Ethnographic Approach." Translation Studies 12 (2): 231-252. doi:10.1080/14781700.2019.1692062.

Zhang, Xiaochun. 2013. "Fansubbing in China." Multilingual, July/August, 30-37. https://www.researchgate.net/publication/279931748_Fansubbing_in_China. 